The Vulnerable Subject 
Also by Amanda Russell Beattie

JUSTICE AND MORALITY: Human Suffering, Natural Law and International Politics

WAR, TERRORISM AND TORTURE: Rethinking the Rules of International Security (co-editor with Anthony F. Lang, Jr)

Also by Kate Schick

GILLIAN ROSE: A Good Enough Justice 


\section{The Vulnerable Subject}

\section{Beyond Rationalism in International Relations}

Edited by

Amanda Russell Beattie

Lecturer in Politics and International Relations, Aston University, UK

and

Kate Schick

Lecturer in International Relations, Victoria University of Wellington, New Zealand 


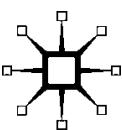

Editorial selection and introduction ( $)$ Amanda Russell Beattie and Kate Schick 2013

Individual chapters and conclusion (c) contributors 2013

Softcover reprint of the hardcover 1st edition 2013 978-0-230-29346-5

All rights reserved. No reproduction, copy or transmission of this publication may be made without written permission.

No portion of this publication may be reproduced, copied or transmitted save with written permission or in accordance with the provisions of the Copyright, Designs and Patents Act 1988, or under the terms of any licence permitting limited copying issued by the Copyright Licensing Agency, Saffron House, 6-10 Kirby Street, London EC1N 8TS.

Any person who does any unauthorized act in relation to this publication may be liable to criminal prosecution and civil claims for damages.

The authors have asserted their rights to be identified as the authors of this work in accordance with the Copyright, Designs and Patents Act 1988.

First published 2013 by

PALGRAVE MACMILLAN

Palgrave Macmillan in the UK is an imprint of Macmillan Publishers Limited, registered in England, company number 785998, of Houndmills, Basingstoke, Hampshire RG21 6XS.

Palgrave Macmillan in the US is a division of St Martin's Press LLC, 175 Fifth Avenue, New York, NY 10010.

Palgrave Macmillan is the global academic imprint of the above companies and has companies and representatives throughout the world.

Palgrave ${ }^{\circledR}$ and Macmillan ${ }^{\circledR}$ are registered trademarks in the United States, the United Kingdom, Europe and other countries.

ISBN 978-1-349-33295-3

ISBN 978-1-137-29214-8 (eBook)

DOI $10.1057 / 9781137292148$

This book is printed on paper suitable for recycling and made from fully managed and sustained forest sources. Logging, pulping and manufacturing processes are expected to conform to the environmental regulations of the country of origin.

A catalogue record for this book is available from the British Library.

A catalog record for this book is available from the Library of Congress.

$\begin{array}{llllllllll}10 & 9 & 8 & 7 & 6 & 5 & 4 & 3 & 2 & 1\end{array}$

$\begin{array}{llllllllll}22 & 21 & 20 & 19 & 18 & 17 & 16 & 15 & 14 & 13\end{array}$ 


\section{Contents}

Acknowledgements vii

Notes on Contributors ix

1 Introduction $\quad 1$

Amanda Russell Beattie and Kate Schick

\section{Part I}

2 A Place of Greater Safety? Securing Judgement in International Ethics

Kimberly Hutchings

3 Gillian Rose and Vulnerable Judgement

Kate Schick

4 Vulnerability, Moral Luck and the Morality of Natural Law

Amanda Russell Beattie

5 Trust, Rationality and Vulnerability in International Relations

Torsten Michel

\section{Part II}

6 'The damage was permanent, there would always be scars': Vulnerability and Accountability in a

Post-Rational World

Brent J. Steele

7 Who Will Provide the West with Therapy?

Robbie Shilliam

8 Pathological Vulnerability and the Politics of Climate Change

Earl Gammon 
vi Contents

9 Between Self-Esteem and Self-Respect: Vulnerability in Japanese Foreign Policy Ryoko Nakano

10 Conclusion

Amanda Russell Beattie

Index 


\section{Acknowledgements}

This project began with two panels at the St Andrews International Political Theory Conference in Scotland, 2010. We would like to thank Patrick Hayden and Anthony F. Lang, Jr, for organising this conference and its predecessor, which provided a unique medium for scholars of international political thought to come together and exchange ideas. We are also grateful to Nicholas Onuf and Richard Beardsworth for their encouragement to move forward with this book project.

We would like to thank all the contributors for their creative and varied contributions and for their willingness to engage with one another's work in ways that illustrate the connections between their different approaches.

In the course of this project we received help and inspiration from our engagement with scholars outside the project. Both of us are grateful to Nick Rengger for his supervision and mentoring as we journeyed from being Master's students to working as academics.

Kate would like to thank her colleagues in the Programme of Political Science and International Relations (IR) and in the Faculty of Humanities and Social Sciences programme for early career academics at Victoria University of Wellington, New Zealand. Particular thanks go to Robbie Shilliam for his advice and support throughout the project and to Simone Drichel and the scholars she brought together for 'Vulnerability: A Symposium' at the University of Otago, Dunedin, New Zealand, in November 2010. She is also grateful to Amanda Beattie for providing the impetus and enthusiasm to put together this volume and for all her support and hard work.

Amanda would like to thank her colleagues in the School of Languages and Social Sciences at Aston University, UK, in particular Nicola Corkin and Jelena Obradovic-Wochnik, for insightful comments on early drafts of this work. Likewise, this project has benefited from research funding from the school, in particular an Early Career 
Grant without which it would not have been possible. Finally, a debt of gratitude goes to Kate Schick, who patiently endured setbacks and missed deadlines as I learnt to juggle the demands of family and project management.

Thank you. 


\section{Contributors}

Amanda Russell Beattie was appointed as a lecturer in 2008 at Aston University. She researches topics emerging within the intersection of international political theory and political philosophy and has previously authored two works, Justice and Morality: Human Suffering, Natural Law and International Politics and War, Torture and Terrorism: Rethinking the Rules of International Security, co-authored with Anthony Lang, Jr. (University of St. Andrews).

Earl Gammon is Lecturer in Politics and International Relations in the School of Political, Social and International Studies at the University of East Anglia, UK. His research examines the psychosocial dimensions of political-economic agency.

Kimberly Hutchings is Professor of International Relations at the London School of Economics, UK. She is the author of several books, including, most recently, Time and World Politics: Thinking the Present (2008) and Global Ethics: An Introduction (2010). Her interests include feminist philosophy, international ethical and political theory, and the philosophies of Kant and Hegel.

Torsten Michel is Lecturer in International Politics in the School of Sociology, Politics and International Studies (SPAIS) at the University of Bristol, UK. His research areas include IR theory, international political theory and security studies. He has published on matters of IR (meta)theory, specifically the concept and role of ontology, as well as on critical terrorism studies and the notion of trust in IR.

Ryoko Nakano is an assistant professor in the Department of Japanese Studies at the National University of Singapore, Singapore. She has published on the history of Japanese political thought and norm diffusion in Japan in journals such as Millennium, International 
Relations and Social Science Japan Journal. She is currently completing a book on the political thought of Yanaihara Tadao as part of the global history of international political thought.

Kate Schick is Lecturer in International Relations at Victoria University of Wellington. Her research lies at the intersection between contemporary political theory and critical security studies and focuses particularly on responses to trauma and suffering in international theory. She is author of Gillian Rose: A Good Enough Justice. This book emphasises the contribution Rose's 'speculative' Hegelianism can make to debates in contemporary radical political theory, arguing that it offers important and provocative lessons for the contemporary Left.

Robbie Shilliam is Senior Lecturer in International Relations at Queen Mary, University of London, UK. He is the author of German Thought and International Relations (2009) and the editor of International Relations and Non-Western Thought (2010). He has published on political thought, slavery and colonialism in a range of journals.

Brent J. Steele is an associate professor in the Department of Political Science, University of Kansas, USA. He is the author of Ontological Security in International Relations (2008) and Defacing Power: The Aesthetics of Insecurity in Global Politics (2010). 